\title{
Cosmopolitan imaginings: creativity and responsibility in the language classroom
}

\author{
Gerdi Quist*
}

School of European Languages, Culture and Society, University College London, Gower Street, London, WC1E 6BT, UK

\begin{abstract}
Appreciating difference and combating intolerance are inadequate to effect intercultural transformative experiences in an age of complexity, ambiguities and mobilities. I argue that the tolerance view of intercultural communication is patronising and does not prepare students for future roles in which they can impact upon the world. To realise their 'obligation to others' students need the freedom to imagine themselves in roles where they engage with others in responsible ways. Utilising sympathetic and dialogic imagination opens up spaces in the classroom where learners can frame their language learning as ethical intercultural engagements. Referring to a case study of an oral presentation task in a Dutch language class as part of a modern language degree, I show how students use their creativity, cosmopolitan perspectives and multiple voices to reauthor themselves as ethical future professionals.
\end{abstract}

Als we interculturele transformatie willen bereiken in deze tijd van complexiteit, ambiguïteit en mobiliteit volstaat het niet om alleen intolerantie tegen te gaan en verschil te appreciëren. Ik beargumenteer dat het tolerantieperspectief van interculturele communicatie betuttelend is en studenten niet voorbereidt op toekomstige posities waarin ze invloed kunnen uitoefenen op de wereld. Om onze 'verplichting tegenover anderen' na te komen, hebben studenten de vrijheid nodig om zichzelf in te kunnen leven in situaties waarin zij met anderen omgaan op een verantwoordelijke en respectvolle manier. Gebruik maken van sympathiek en dialogisch inlevingsvermogen creëert ruimte in de vreemdetaalklas waarin studenten hun taalactiviteiten kunnen plaatsen binnen een ethisch intercultureel kader. Ik verwijs naar een casusstudie van een mondelinge presentatie tijdens een les Nederlands als vreemde taal, en laat zien hoe studenten hun creativiteit, cosmopolitisch perspectief en hun meerstemmigheid gebruiken om zichzelf neer te zetten als toekomstig beroepskundige individuen.

Keywords: ethical intercultural engagements; sympathetic imagination; dialogic imagination; cosmopolitan perspectives; heteroglossia

\section{Introduction}

In a climate where hyper-rationalism and instrumentalism reign supreme, the role of creativity and imagination in higher education - and much of public life - is hardly receiving any attention. Equally, another aspect of human life and, indeed, intercultural relations - our responsibility towards others, lies largely unexplored, at least it does in language teaching. Whilst creativity and imagination might seem to belong to a domain of freedom, art and flights of fancy and the notion of

\footnotetext{
*Email: g.quist@ucl.ac.uk
} 
responsibility seemingly occupying another part of the spectrum that speaks of seriousness, morality and grounding, both are in fact - to paraphrase Kramsch - two sides of the same coin. In this article, I locate creativity and responsibility in the theoretical realm of the imagination - both sympathetic and dialogic. Imagination is not only a powerful concept in encouraging individuals to engage creatively with language, it also is a necessary condition to be a cosmopolitan global citizen. I argue that imagination holds the key to helping the learners to frame their language learning as ethical intercultural engagements. Using a case study of an oral presentation task in a fourth-year Dutch language class as part of a modern language degree, I will show how the students, when asked to imagine their own roles in a language task utilise their creativity, their 'sympathetic imagination' and a concern for others. They do this both in terms of the imagined aim they hoped to achieve with their presentation and the way they direct their language use to the audience.

\section{Sympathetic imagination problematised}

In 1999, Jo Carr, reflecting on intercultural competence in language education, wrote a chapter called "From "sympathetic" to "dialogic" imagination: cultural study in the foreign language classroom' (Lo Bianco, Liddicoat, \& Crozet, 1999). In this chapter, she argued that teachers needed a new conceptual tool kit for language pedagogy to effect intercultural transformative experiences which go beyond the idea of developing tolerance and empathy in language learners. She felt 'sympathetic imagination' was inadequate as it only aims to appreciate difference. Instead, she argued for a more active engagement where learners also do difference. She suggested that the theoretical toolkit for teachers which would aid such an outcome is 'dialogic imagination'; language encounters as cultural interstices where multiple voices carrying traces of particular historical, political and social contexts and experiences intermingle with the learners' own multiple voices (Carr, 1999, pp. 105-110).

Fourteen years later, her argument is still fresh as the idea of 'dialogic imagination' is an important one for language learning in a complex world where frequent change, mobilities, ambiguities and uncertainties are common features of people's everyday lives. But whilst 'dialogic imagination' deserves to be further explored for language pedagogies which allow engagement with and reflection on intercultural experiences - and, indeed, I will do further below, the notion of 'sympathetic imagination' was perhaps ditched too early.

Carr's critique of sympathetic imagination relates to a particular view, namely, the idea of 'being tolerant' towards others and understanding and accepting difference in order to avoid possible conflict or tension and to ensure good relations between groups are maintained (Carr, 1999, p. 103). As Carr says, this notion of tolerance is often enshrined in the programme objectives of language courses. Carr was referring to the Australian context of language education in the 1990s, but the view she highlighted also underlined the work by the Council of Europe's Common European Framework (2001), which emphasises aims such as tolerance and combating xenophobia by understanding others and their points of view. Whilst these are important aims (after all, which language teacher would not want to encourage intercultural understanding?), this view of sympathetic imagination, as Carr points out, leaves differences intact. It generates a 'discourse of containment' which freezes culture as 'essentialised colourful difference' (1999, p. 103). Such a view 
of sympathetic imagination does not match the complex realities of the lived experience of our students. It avoids the discomfort of having to rethink oneself and one's views and, indeed, it avoids rethinking the other who remains encapsulated in his or her role of 'being other'.

There is another downside to the idea of 'sympathy' with others if this is based on supposed characteristics of groups of people, and that is that it can all too easily lead to a patronising stance of 'pity' and only serves to confirm attitudes of superiority towards others. We are all familiar with the mass media representations of Africa and Africans in terms of poverty and famines, ignoring other narratives of strength, development, creativity, innovation and human dignity which are equally to be found in that same continent. Even visitors and tourists who take an interest in the lived experience of local people beyond the well-developed tourist areas echo these 'sympathetic' sentiments, remarking on the poverty they encounter and how lucky they count themselves having access to comparative luxuries and comfort. Whilst there is in itself nothing wrong with such a realisation, its sympathetic stance positions the foreign locals in terms of their disadvantages, taking Western luxuries as the norm, which it is assumed that all Africans would aspire to equally. It ignores pride in achievements and advances made, such as the pride people feel about the school achievements of their children or in the joint rice harvest, or in the recently bought heavy furniture - even if it rests on a compacted sandy floor rather than a concrete one. Whilst it is, indeed, part of the 'cosmopolitan project', as Appiah (2006) calls it, that we are concerned that all have a decent way of living and that basic human rights are upheld everywhere, notions of sympathy like the one described here continue the discourse of unequal power relations and Western superiority. Following Derrida, MacDonald and O'Regan (2012) suggest that tolerance is a 'form of charity' (MacDonald and O'Regan, 2012) and not part of what Appiah (2006) calls 'our obligation to others'.

Another problem with the tolerance 'project', as MacDonald and O'Regan (2012) point out, is that the idea of tolerance poses ethical problems when we are faced with what we find 'intolerable' practices. If we take the tolerance view of intercultural relations to its logical conclusion, MacDonald and O'Regan (2012) state, we would have to accept the 'unacceptable', such as honour killings or female genital mutilation. Or if we want to claim that certain practices are unacceptable, then we have to make a claim that our view of right and wrong is the only correct one, which is then open to the charge of being an opinion. The danger, they say, would be that some 'truths' about how we should live our lives and what is acceptable, could become dominant. The point is not, as they say, to determine whether certain 'truths' are good or bad, but whether particular discourses in practice, i.e. particular 'truths', would silence alternative ones. The guiding principle for this, they say, pointing us to Levinas, amongst others, is a 'responsibility' towards and insistence on not reducing the other. This way we could oppose unacceptable practices not because we have the 'correct' view of how we should live, but because it would be irresponsible not to do so. Appiah (2006) also frames the question of tolerance in relation to responsibility: how do we intertwine respecting cultural particularities with our 'obligation to others'? If each is right from his perspective, he states, then we live in separate worlds, and there is no need to engage with others or to have 'conversations'. In fact, it would be a reason to fall silent (2006, p. 31).

The 'tolerance take' on sympathetic imagination does not expect us to engage with responsibility or act upon our obligation to others. This view then does not aid 
an 'ethical intercultural dialogue' (MacDonald \& O'Regan, 2012) or the 'cosmopolitan project' (Appiah, 2006). However, the concept of sympathetic imagination does not have to be rooted in an extreme form of cultural relativity, which accepts difference at all costs and maintains a strict separation between oneself and the 'cultural other', nor does it have to take on a patronising stance towards the other. We can conceptualise it in a way which can help learners to negotiate intercultural complexities creatively and responsibly leading to more transformative experiences of looking at others and oneself. But before I return to this discussion again and alternative ways of thinking about sympathetic imagination, I need to discuss its counterpart: 'dialogic imagination'.

\section{Dialogic imagination}

To return to Carr (1999), she posed the idea of dialogic imagination as a conceptual toolkit, which would aid language learners' conceptualisation of language encounters as meeting places where historical, social and personal experiences mingle and intersect. Not the limited view of matching language to particular situations in rigid and prescripted communicative exchanges, but, instead, conceptualising encounters as 'dialogue'; where matching language to context is characterised by indeterminacy and heterogeneity - communicative situations where meaning is created and made in a messy way, with overlaps and collisions and where 'settled truths become unsettled' (Carr, 1999, p. 107).

Earlier on, Kramsch (1993, p. 28) referred to 'dialoguing imaginations' and 'dialogic breakthrough' in relation to Attinasi and Friedrich's concept of 'lifechanging conversations (1994)'. The notion of dialogic imagination has, however, not been taken up widely in language pedagogy literature, as the notion of the 'Intercultural Speaker' gained dominance instead. The notion of the intercultural speaker emphasises dialogue between cultures by reflecting on comparisons between the target culture and that of the learner. Whilst the concept of the intercultural speaker carries some elements of dialogic imagination in its reflection on self and other, the intercultural speaker does not necessarily 'do difference', as Carr calls it. It does not lead to 'transformation' or boundary crossing 'conversations'. And whilst the intercultural speaker is open and curious about the other, she operates from a fairly fixed notion of culture rather than taking the fluidity and contradictions of intercultural engagements into account. He or she, as Ros i Solé (2013) points out, does not move in and out of and in-between different cultures. And, of course, by extension the 'other', the communicative partner, remains immobile within his culture, as well. Instead, Ros i Sole (2013) poses the notion of the Cosmopolitan Speaker. This is a more complex articulation of the concept of the Intercultural Speaker - an articulation, which takes account of the cultural complexity of the dialogic partners. Ros i Solé (2013) points us to Beck's 'cosmopolitan outlook' as she conceptualises the Cosmopolitan Speaker as being 'defined by his/her multiple cultural alliances and the development of a nomadic and borderless lifestyle'. In emphasising creativity, the co-construction of meaning and the personal and intimate perspective as part of the intercultural engagement of the language learner, the notion of the Cosmopolitan Speaker seems to be one which is defined by 'dialogic imagination'. It also challenges the idea that the learner locates her cultural identity in a single national culture. Instead, it allows the learners to see themselves as operating across and between various cultures and cultural subjectivities. I will 
come back to pedagogical implications of the Cosmopolitan Speaker below, but first I want to explore the notion of dialogic imagination further.

The concept of 'dialogic imagination' was posed by Bakhtin (1981) both as a way of conceptualising language in use and as a philosophy of human consciousness in its focus on the development of 'selves'. We develop our sense of who we are through 'dialogic encounters' with others in different areas of daily life, using and experiencing many different 'speech genres' and discourses. Bakhtin (1981) calls these dialogic encounters, this multiplicity of language, 'heteroglossia'; multiple voices and multiple discourses which reflect, as well as construct, ways of viewing the world. As we come across and experience different areas of social life, different social activities and different ideas through our dialogic encounters, we develop our complex and multifaceted selves. These fragmentary and, at times, contradictory subjectivities keep forming and being rearticulated in the process of engaging with others as we move in different social, professional, cultural or lifestyle groups. These dialogic encounters are not static situations, where the language and the outcomes are fixed. Instead, they are 'struggles for meaning' as the self comes to respond and appropriate voices of others.

\section{Struggle for meaning}

This struggle for meaning is caused by the fact that, on the one hand, the speaker needs to use existing language, which already has meanings imprinted upon it and is infused with connotations. In speaking, we use words, which are 'half someone else's', words which have already been 'in other people's mouths' (Bakhtin, 1981, p. 293/294) with their social, cultural and historically accentuated meanings, connotations and conventions. On the other hand, the speaker is not a prisoner of these existing meanings of 'others' in language. We may use words, which are typical of particular speech genres, but we articulate them with our own voices. After all, dialogic encounters take place between individuals whose own complex subjectivities or 'belongings' are formed - and keep on forming - through engaging with different social and cultural realities developing a range of cultural allegiances in the process. Vitanova (2005) refers to Davies (2000) to explain that the individual 'can move between discourses; reflect on how they position him or her; and can negotiate, modify or even resist them in the process of experiencing one's subjectivities'. By appropriating language for their own purposes, learners are 'authoring themselves' (Vitanova, 2005). In using another's language, students reimagine themselves and bridge the larger domains of social and cultural activity with individual ways of authoring subjectivities (Vitanova, 2005, p. 153). This is a creative process where the boundaries between ourselves and others are blurring.

Indeed, there is another aspect of dialogic imagination, which makes it so useful for the idea of intercultural engagement; it also provides a way of conceptualising communication in terms of our responsibility towards others. Bakhtin (1986, p. 99) calls this being directed to the person you address 'addressivity' or 'the quality of turning to someone'. The speaker or author imagines his or her dialogic partners and attempts to engage with them respectfully, acknowledging their complexity and trying to understand what they feel like and address them as equals.

Dialogic imagination then is a powerful and creative tool for boundary crossing and meaning making. Its focus on language as being complex, consisting of multiple voices and carrying traces of histories, being directed to others, has many of the 
ingredients for a pedagogy of cultural complexity and complex cultural subjectivities - a pedagogy for the Cosmopolitan Speaker (Ros i Solé, 2013).

\section{Cosmopolitan approaches to dialogic and sympathetic imagination}

Beck (2002) refers to 'dialogic imagination' as the central defining characteristic of a cosmopolitan perspective. He does not focus so much on meaning and communicative encounters, but as a sociologist, he sees dialogic imagination as an alternative to the national perspective, or 'monologic imagination', which 'excludes the otherness of the other'. Dialogic imagination in everyday practice as part of a cosmopolitan outlook, Beck says, involves two things - on the one hand, being aware of your own horizons of possibilities and being able to relativise and reflect on these, and on the other hand, to be able to see something from the perspective of cultural others. To achieve this, we need to exercise 'boundary-transcending imagination' (Beck, 2006, p. 89). Beck tells us that this question of how this could be facilitated has hardly been investigated or even posed, although the position of reflecting on the self and other and trying to see the world from others' perspectives by looking in detail at micro situations is already a familiar one to language educators through the practice of ethnography for language learners (Roberts, Byram, Barro, Jordan, \& Street, 2001). This ethnographic practice tries to see the perspective of others through a rigorous method of 'close observations'.

However, this 'boundary-transcending imagination' is also taking place, almost automatically, when we read a novel or watch a film and try to inhabit the lives of the characters by projecting ourselves into their shoes. This imagination, this projection, is a creative process through which we try to see the world through someone else's eyes and feel their feelings. Through this creative process, we are more likely to gain sympathy and, hence, we feel a concern for the fictional others.

This brings us back again to the idea of sympathetic imagination, albeit from a different angle than the 'tolerance view', often highlighted by language programmes for intercultural communication.

Beck sees this sympathy with others also as one of the aspects of his 'cosmopolitan outlook'. People feel an empathy to the suffering of others on a global scale; they feel affected by wars and famines taking place far away. Beck calls this the 'globalisation of emotions' or 'cosmopolitan empathy', in part occasioned, he admits, by media images (2006, p. 6). Whilst this might be seen to be a form of 'pity' leading to unequal relations, the idea that people are willing to put themselves into victim's shoes, and especially act upon it whether through protests or giving donations to lessen the suffering of others, is a way of showing concern for others and taking responsibility.

Ros i Solé (2013) also points us to the importance of empathy towards others. The Cosmopolitan Speaker engages and empathises with the world and the moral dilemmas of the culture under study. The Cosmopolitan Speaker is affected by the emotion of other peoples' suffering (Ros i Solé, 2013).

This Cosmopolitan Speaker, I would suggest, is also concerned with the ethical relations within a cosmopolitan world, and her concern remains not only at the level of pity but also focuses on her responsibility towards others, beyond joining protest marches or giving financial donations for large-scale disasters. This Cosmopolitan Speaker makes a concerted effort to engage with others with 'intelligence' and 'curiosity', as Appiah formulates, through our 'obligation to strangers' (2006, p. 168). Not just the warm fuzzy feeling of togetherness, Appiah indicates. Not just an 
explosion of feelings, but also trying to understand that what causes suffering and cultural dilemmas.

For the Cosmopolitan Speaker, imagination, both dialogic and sympathetic, becomes a crucial tool. Through dialogic imagination we form and reform our multifaceted selves in a constantly shifting dialogue with others, appropriating their voices to differing extents. And through sympathetic imagination we imagine ourselves in the shoes of others with an understanding that we are part of a larger cosmopolitan project which compels us to take responsibility for others, work towards justice, equality, respect and even friendship.

\section{Imaginations in the classroom}

So what would a cosmopolitan pedagogy for dialogic and sympathetic imagination look like? I am not pretending to be able to give a definitive answer to that question, but an important element of this would be to create spaces in the classroom where students can use their creativity to engage with people, views, situations - social, cultural, political, historical or everyday - in dialogic ways and from a position of justice, equality and respect for the other. This is not achieved through just acting out a role and pretending to be someone else based on a monologic idea of that other. It is not achieved by focusing on certain restricted phrases and restricted rules for communication. Instead, we need to give students the freedom to appropriate these voices or rearticulate them and to rely on their own experiences as they 'struggle to make meaning' as they see fit. This would be a pedagogy that gives the students an opportunity to get under the skin of the people whose voices they are trying to inhabit, with their complexity and humanity. Ros i Sole (2013) also emphasises the personal and intimate perspective as part of intercultural engagements of the language learner; 'cosmopolitan language learners invest their emotional selves and create a personal space that is not only defined by the here and now, but by their personal histories and by their projects for the future'.

This view of dialogic imagination directs us towards language pedagogies where the social and cultural connotations of language are highlighted, where sociolinguistic language varieties are encountered and where language is consciously directed at others taking their circumstances into account. Moreover, it directs us to pedagogies where the learner can find spaces to reimagine him or herself in the classroom in a range of situations and where he or she reflects on the relations and the encounters and the language used. A pedagogy where learners, as well as their dialogic partners, are seen as complex cultural beings.

Such a pedagogy can be effected in many ways, and I am sure many teachers are already including imagination in very creative ways in classrooms, using tools such as drama or creative writing techniques. I believe these techniques could be explored to a greater extent than they have been so far so that they give students the freedom to use their imagination in their language tasks and engage creatively with this. In the next section, I will be providing an example of a seemingly more traditional language task in order to illustrate what such a pedagogy could look like and what it achieves.

\section{Case study: an oral presentation}

One of the activities I ask students to do in the final-year language class is to give an oral presentation for which they need to create the context. They need to imagine 
what their role is, who their audience is, where the presentation takes place and why they give this presentation in the first place. I ask them to structure their presentation in terms of content, language and tone accordingly. The only criterion I give them is that the context should be a work context, and that ideally, the topic of the presentation should relate to the research project they have carried out during the time they spent in the Netherlands or Flanders as part of their Residency Abroad projects which have a social or cultural focus. The advantage of using these projects as a starting point is that students are knowledgeable about the topic and can take on the role of an 'expert' or professional confidently. They are also likely to take a strong personal interest in the topic. In this task, students are not only reimagining themselves, they also reimagine their fellow students in the classroom in the role of audience members.

The cohort of students this year, without being prompted to do so, all imagined themselves in border-crossing transnational contexts, where they wanted to instigate social change to achieve better intercultural communications or improve living conditions for disadvantaged groups. Students took their responsibility to their audience seriously. They did this in terms of the way they addressed them through language, tone and indeed making sure their listeners would stay 'on board' throughout the presentation. Students also took their responsibility from a cosmopolitan perspective, their 'obligation to others', in terms of their imagined aim - what they wanted to achieve in their presentation. For instance, one student, Rose, utilised her interest and knowledge of economy. Her context was an international meeting of bankers and charity workers intended to create a dialogue of cooperation in relation to a particular microcredit scheme in Africa. And Jessica, who had carried out an ethnographic project in Flanders with the family where she had worked as an au pair, had chosen the context of an information evening for parents who were thinking about bringing up their children bilingually. In her role as a linguistic expert, she presented various arguments in favour of doing so and provided practical advice. At the same time, she was able to show a sympathetic understanding towards the imagined parents' concern. But, below, I focus in greater detail on the presentation of another student, Ilona.

\section{Ilona's reimagined self: webmaster of a skateboard Internet page}

Ilona was interested in the relationship between communication technologies and social organisations and had carried out a research project on this topic whilst living in Amsterdam for her Residency Abroad. She is also a keen skateboarder. She utilised these personal and academic interests and experiences in setting the context for and performing her oral presentation as 'a meeting between various stakeholders of a collaborative youth project'. The project was located in the Bijlmer, a large multicultural area in the outskirts of Amsterdam with a high proportion of social housing and a reputation in the media for crime and muggings. The project aimed for several youth centres in the Bijlmer to work together with a nearby skatepark to reach otherwise disengaged teenagers and to provide support. The skatepark was frequented by many Surinamese young skateboarders, alongside 'native' Dutch, Moroccan and Turkish ones. The role Ilona had designed for herself in this presentation was that of the webmaster of the Internet page 'Tacky.nl', an important resource for the skateboarding community. In her imagined capacity as the webmaster, she conceived her aim of the presentation as informing the various stakeholders of the project about 
the role the Internet could play in the project as a whole. In this sense, she conceived her reimagined self as contributing to the wider community by helping to better intercultural relations amongst young people in the Bijlmer.

\section{Ilona's imagined audience}

Part of the oral presentation task was for the student doing the presentation to prepare their fellow students for their roles. To that end, each student giving a presentation had to inform his or her fellow students a few days beforehand about these roles and the general context. My main pedagogical intention in asking students to imagine their audience was so they could carefully consider how to position their audience and, indeed themselves, and manage that relationship.

Ilona had imagined her audience as consisting of stakeholders with different agendas. For instance, she gave two students the roles of being representatives of funding agencies. One of them she described as follows:

Jessica: 45 years old. Representative of the programme 'Increasing Diversity in Youth Policy' at the Ministry of Health. The Ministry has already approved the project and has contributed funding, but she is attending the meeting to monitor the project (and maybe to gain some positive attention in the media?).

Another stakeholder she described as follows:

Emily: 37 years old, teacher of a secondary school in De Pijp in Amsterdam. She has worked as a volunteer at Skatepark Amsterdam and is responsible for the new programme in the Bijlmer. She has worked with Rose in the past (whose role was to be a PhD student carrying out research on the project) on an intercultural programme at the school.

The other imagined stakeholders were representatives of respectively the youth centres and the skate park itself.

In choosing to have such a range of roles and imagining others present at the meeting, Ilona had created a context of unequal and hierarchical relations. Ilona did so purposefully, as she described afterwards, and was aware she needed to 'manage' these differences during her presentation. In her self-evaluation of her presentation, she said the following about 'managing' these hierarchies, which she referred to as different 'levels':

I chose to have a rather informal tone in my presentation. Since my presentation was part of a project between various different actors, from different institutions and 'levels', I felt it was important to keep it friendly, 'down-to-earth' and informal since all the actors contribute equally to the project regardless of their individual positions. [...] Therefore, I wanted the tone of my presentation to reflect the relationships among me and the audience, and between the different individuals in the audience, as equal and casual. Moreover, the skateboarding community I was supposed to represent is quite informal and relaxed, with little hierarchy. So I felt it was important that this was reflected in my tone and presentation itself.

It is clear that Ilona had conceptualised her responsibility both in terms of the aim of her presentation, improving intercultural relations as well as in terms of 'addressivity', the way she addressed the audience after having imagined them sympathetically. After 
all, with a representative of the Ministry of Health present, as one of the funding partners (and one with a 'hidden agenda'), she had imagined other stakeholders at the meeting, e.g. the youth centre workers, could feel intimidated by these different hierarchies. Her solution was to adopt an informal tone. In this way, Ilona also created a reimagined personal voice, one that 'belonged' in the skateboarding community.

\section{Heteroglossia}

Ilona did not only speak with one voice, but with multiple ones. She became a heteroglot. The range of voices that Ilona employed in her presentation were personal, academic and professional. Apart from the young skateboarding voice which came through in various parts of the presentation, Ilona employed an 'academic voice' in the main body of the presentation, where she quoted research. This helped her to present herself as knowledgeable about her topic. She spoke both with the confidence of an academic as well as a young skateboarder. But, she also employed 'professional' voices.

Below is Ilona's introduction, where we can see how she does this:

"Good morning everyone,

You all know one another, and I see a few familiar faces, but to be on the safe side:

My name is Ilona Min and I am webmaster for Tacky.nl.

If I understand correctly, Skatepark Bijlmer and Youth Centre Bijlmer have already started working together on the project. So I assume you have already some insight into skateboarding and young people, also because Emily is already a familiar face in this world. But could you all just give me a short intro about your role in this project, so I can get an idea of how much you know and understand about skateboarding?"

[audience members introduce themselves]

“Thanks. I think it's really cool that so many different organisations are involved in this project. It's great to see that the skateboarding community is being considered seriously, and anyway, I think that's a good strategy for the Bijlmer. We can see why this is the case in the next YouTube clip which we have put on our website."

[Ilona then shows a video clip from 'her' website which shows skateboarding as a way of improving communities and forging intercultural relationships]

"So, this is what I am imagining your project is about. What I have been asked to do is to give a short introduction about the important relationship between skateboarding and the Internet. The next 15 minutes or so, I will show why the Internet is an essentially integrated part of the skateboarding community. And hopefully this will make it clear why it is so important for you to be visible and accessible on the Internet.'

In short, I will touch on three points. First I want to tell you more about Tacky.nl and our experiences. How WE can help you with your project. Then I will focus on the main issue: in what ways is the Internet so crucial for the skateboarding community? To conclude I will try and give you some tips, and [address] how your collaborative project can develop from here."

NB In my translation of Ilona's actual words, I tried to stay as close to her original words and style as possible $(G Q)$. 
In the first part of her introduction (up until where she shows the video clip), we can see how she manages her relationship with her audience by addressing some of these relationships explicitly. She is careful not to create distance between herself and the audience by not taking the position of the all-knowing 'expert' about the project. She checked, for instance, that she had understood the current position of the project correctly and positions her audience as having knowledge about the skateboarding world. She further acknowledges that some of the imagined audience members might actually already know one another and some also have some standing in the community (e.g. the teacher) because of their previous work in the field. As we saw above, she consciously wanted to employ an informal tone. In this first section of the presentation, she creates this tone using both a personal and a professional voice. Her professional voice is both confident and caring in the way she tried to smooth over potential difficult relations, asked stakeholders to introduce themselves and her positive comments on the project.

Ilona had also thought carefully about the informality that she tried to create and how to express this linguistically:

I felt the informal tone was reflected through my use of "je" (you, inf.) and not the formal " $U$ " (you, form.) And also the flow of my presentation, I tried to use words and sentences which you mostly hear in spoken-language. And I also tried to use a youthful language, as I was supposed to represent a youthful community. For instance, I chose to use some English words, as this is something which you can hear quite often among young, Dutch people. Especially in the skateboard community, where many of the tricks and words within the community are in English, it is common to use English words, or "Dutchified" English words. Even though I used some academic terms, especially (in the main body of the presentation, $G Q$ ) when talking about the effects of the Internet for the community, I felt the overall tone was still casual.

As I said earlier, Ilona spoke with two different professional voices. The first one, she employed in managing the audience relations. Her second one she employed in managing the audience expectations. In the second part of the introduction (after she had shown the video clip), we can see that her voice becomes more conventionally professional. She uses conventional markers to indicate the structure of her talk to the audience: 'the next 15 minutes or so'; 'in short, I will touch on three points'; 'then I will focus on'; 'to conclude I will try'. It might, of course, be the case that Ilona was resorting to more standard linguistic phrases, often used in formal presentations, because the presentation was assessed, and she may have wanted to show she was aware of these conventions. I had, indeed, introduced some of these phrases in a previous lesson as 'standard' and 'conventional'. At the same time, I also generally warn students against using 'standard' phrases too often, precisely because these can lend an unnatural and unauthentic feel. Yet where Ilona is concerned, despite the slight distance and formality created by using these phrases, it could be argued she used these conventional phrases as part of her sense of responsibility to her audience to make sure they were aware of the structure of the meeting as a whole. By using these phrases, she underlined her role as a professional who came to impart knowledge even if this differed from her role as a 'mediator' between the various professional cultures and agendas.

By using her sympathetic and dialogic imagination, Ilona acted as a Cosmopolitan Speaker showing a concern for others in lending her knowledge to contribute to a project, which would help social and intercultural relations. She also 
took a responsible stance to her audience in trying to ensure that they all felt respected, included and made aware of what was going on.

\section{Conclusion}

Tasks such as these, which encourage students to employ their creativity by using their sympathetic and dialogic imagination, and what I would term 'cosmopolitan imaginings' open ways for students to imagine themselves in future roles where they have impact and effect on the world. The stance of responsibility towards others in terms of being concerned with inequality, wanting to contribute as a global citizen to a 'better world' and treating others with respect, was shown by all students who participated in this task. I believe that the students already had these attitudes, and these were not necessarily developed through the pedagogy itself. After all, students are already Cosmopolitan Speakers. Students already live cosmopolitan, complex and mobile lives. Some have complex multicultural backgrounds, most have travelled widely or have friends across the world. Many participate in communication networks and, generally, engage on a daily basis with many different and changing ideas and transnational discourses through the media, digital networks and face-toface. Even though my pedagogy addresses a consideration of the audience and emphasises an awareness of multiple voices and discourses, the most important aspect of the kind of pedagogy I am advocating is to open up spaces in the classroom. These would be spaces where students can engage with the cultural 'other' by trying to get under their skin; spaces where students can 'author' themselves in creative and responsible ways, representing both themselves and their dialogic partners as complex individuals.

It is the imagination aspect of the pedagogical tasks, which set students free to construct and imagine their own roles. In doing so, they used their cosmopolitan perspectives and rich personal experiences. They visualised themselves as actors in a complex world with a sense of responsibility, both in ethical terms in having impact on the world and in how they directed their language to the other, ensuring people would not lose face and felt respected and positioned as equals.

A pedagogy of imagination is a pedagogy of freedom. It means that as teachers, we need to find ways of language teaching where we can loosen the bounds of the conventions and expectations which instrumentalist language teaching imposes upon us. As my cohort this year showed, when given this freedom, our students imagine the way we can go.

\section{Notes on contributor}

Gerdi Quist is based at University College London in the School for European Languages and Culture, where she teaches Dutch language and lectures on multiculturalism and intercultural communication. She has published on the teaching of language and culture, taking complexity and critical intercultural awareness as a starting point. She has also written a number of textbooks for Dutch as a Foreign Language. She has currently just finished a book on the use of 'text as culture' as a critical approach to language teaching in Higher Education. 


\section{References}

Appiah, K. A. (2006). Cosmopolitanism: Ethics in a world of strangers. London: Penguin.

Attinasi, J., \& Friedrich, P. (1994). Dialogic breakthrough: Catalysis and synthesis in lifechanging dialogue. In B. Mannheim \& D. Tedlock (Eds.), The dialogic emergence of culture (pp. 33-53). Urbana: University of Illinois.

Bakhtin, M. (1981). Discourse in the novel. In M. Holquist (Ed.), The dialogic imagination: Four essays. Austin: University of Texas Press.

Bakhtin, M. (1986). Speech genres and other late essays. Austin: University of Texas Press.

Beck, U. (2002). The cosmopolitan society and its enemies. Theory, Culture \& Society, 19(1-2), 17-44. Retrieved from http://www.veraznanjemir.bos.rs/materijal/BECK_the_cosmopolitan_society_and_its_enemies.pdf

Beck, U. (2006). Cosmopolitan vision. Cambridge: Polity Press.

Carr, J. (1999). From 'sympathetic' to 'dialogic' imagination: Cultural study in the foreign language classroom'. In J. Lo Bianco, A. Liddicoat \& C. Crozet (Eds.), Striving for the third place: Intercultural competence through language education (pp. 103-112). Deakin: The National Languages and Literacy Institute of Australia.

Council of Europe. (2001). Common European framework. Cambridge: Cambridge University Press.

Davies, B. (2000). A body of writing: 1990-1999. Walnut Creek, CA: Alta Mira.

Kramsch, C. (1993). Context and culture in language teaching. Oxford: Oxford University Press.

Lo Bianco, J., Liddicoat, A., \& Crozet, C. (Eds.), (1999). Striving for the third place: Intercultural competence through language education. Deakin: The National Languages and Literacy Institute of Australia.

MacDonald, M. N., \& O’Regan, J. P. (2012). The ethics of intercultural communication. Educational Philosophy and Theory, doi:10.1080/00131857.2012.753377

Roberts, C., Byram, M., Barro, A., Jordan, S., \& Street, B. (2001). Language learners as ethnographers. Clevedon: Multilingual Matters.

Ros i Solé, C. (2013). Cosmopolitan speakers and the new cultural order. The Language Learning Journal, 41, 3.

Vitanova, G. (2005). Authoring the self in a non-native language: A dialogic approach to agency and subjectivity. In J. K. Hall, G. Vitanova \& L. Marchenkova (Eds.), Dialogue with Bakhtin on second and foreign language learning: New perspectives. Mahwah, NJ: Lawrence Erlbaum Associates. 